Ponastassiou, D. A., and G. J. Wasserburg, Initial strontium isotopic abundances and the resolution of small time differences in the formation of planetary objects, Earth Planet. Sci. Lett. 5, 361-376, 1969 .

anin $R .0$., Heavy rare gases in silicates from the Esterville Tesosiderite, J. Geophys. Res., 71, 2815-2829, 1966.

popin, R. O., Trapped neon in meteorites, Earth Planet. Sci. Let., 2, 13-18, 1967

Levir, R. O., and P. Signer, Primordial rare gases in meteorites. Solence, $149,253-265,1965$.

folosek, F. A., Dating of meteorites by the high-temperature rease of iodine-correlated $\mathrm{Xe}^{229}$, Geochim Cosmochim. Acta, 34, 341-365, $1970 a$.

Podosek, F. A., The abundance of Pu-244 in the early solar system, Earth Planet. Sci. Lett., in press, $1970 \mathrm{~b}$.

ancitelli, L. A., and D. E. Fisher, Potassium: Argon problem in ron meteorites, J. Geophys. Res., 73, 5429-5437, 1968.

Rancitelli, L., D. E. Fisher, J. Funkhouser, and O. A. Schaeffer, Potassium: argon dating of iron meteorites, Science, 155, 999-1000, 1967.

360, M. N., R. S. Clark, and P. K. Kuroda, Excess xenon-128 in meteorites, Astrophys. Space Sci., I, 513-518, 1968a.

Roo, M. N., J. L. Meason, and P. K. Kuroda, Plutonium-xenon and iodine-xenon chronology of three light-dark structured thondrites, Icarus 8, 481-485, $1968 b$.

Reynolds, J. H., Xenology, J. Geophys. Res., 68, 2939-2956, 1963.

Reynalds, J. H., Isotopic abundance anomalies in the solar system, Ann. Rev. Nucl, Sci., 17, 253-316, 1967.

Revrolds, J. H., Plutonium-244 in the early solar system, Nature, 218, 1024-1028, 1968 a

Revnolds, J. H., Extinct radioactivities and the history of the Rements and the solar system, Origin and Distribution of the Elements, edited by L. H. Ahrens, pp. 367-377, Pergamon, New York, $1968 b$

Reynolds, J. H., Xenon problems in meteorites: A review, paper presented at the International Conference on Mass Spectroscopy, Kyoto, Japan, September, 1969.

Reynolds, M. A., M. N. Rao, J. L. Meason, and P. K. Kuroda, Fissiogenic and radiogenic xenon in the chondrites Beardsley and Holbrook, J. Geophys. Res., 74, 2711-2716, 1969

Rowe, M. W., Cosmic ray spallation and the special anomaly in achondrites, Earth Planet. Sci. Lett., 2, 92-98, 1967.

Rowe, M. W., On the origin of excess heavy xenon in primitive chondrites, Geochim Cosmochim. Acta, 32, 1317-1326, 1968.

Nowe, M. W., and P. K. Kuroda, Fissiogenic xenon from the Pasamonte meteorite, J. Geophys. Res., 70, 709-714, 1965.
Rowe, M. W., D. D. Bogard, C. E. Brothers, and P. K. Kuroda, Cosmic-ray-produced xenon in meteorites, Phys. Rev. Lett., $15,843-845,1965$

Rowe, M. W., D. D. Bogard, and P. K. Kuroda, Mass yield spectrum of cosmic-ray-produced xenon, $J$. Geophys. Res., 71 , $4679-4684,1966$

Sabu, D. D., and P. K. Kuroda, Plutonium-244 in the early solar system and concordant plutonium/xenon and iodine/xenon decay intervals of achondrites, Nature, 216, 442-446, 1967.

Sabu, D. D., and P. K. Kuroda, Fission xenon in chondrites, $J$. Geophys. Res., 73, 3957-3964, 1968.

Schaeffer, O., J. Funkhouser, D. Bogard, and J. Zăhringer, K-Ar ages of lunar rocks from Mare Tranquillitatis and Oceanus Procellarum, Science, 170, 161-162, 1970.

Schultz, L., and $\mathrm{H}$. Hintenberger, Edelgasmessungen an Eisenmeteoriten, Z. Naturforsch. $A, 22,773-779,1967$.

Stoenner, R. W., O. A. Schaeffer, and R. Davis, $J_{r}$., Meteorites as space probes for testing the spatial constancy of cosmic radiation, J. Geophys. Res., 65, 3025-3034, 1960.

Tanenbaum, A. S., Clustering of the cosmic-ray ages of stone meteorites, Earth Planet. Sci. Lett., 2, 33-35, 1967.

Taylor, G. J., and D. Heymann, Shock, reheating, and the gas retention ages of chondrites, Earth Planet. Sci. Lett., 7, $151-161,1969$.

Turner, G., Thermal histories of meteorites by the Ar-39/Ar-40 method, in Meteorite Research, edited by P. M. Millman, pp. 407-417, D. Reidel, Dordrecht, Holland, 1969.

Turner, G., Ar-39/Ar-40 dating of lunar rocks, Geochim. Cosmochim. Acta, Suppl. 1, Proceedings of the Apollo II Lunar Science Conference, 1970.

Wanke, H., Der Sonnenwind als Quelle der Uredelgase in Steinmeteoriten, Z. Naturforsch. A, 20, 146-149, 1965.

Wänke, H., Meteoritanalter und verwandte Probleme der Kosmochemie, Fortsch. Chem. Forsch., 7, 322-408, 1966.

Wasserburg, G. J., J. C. Huneke, and D. S. Burnett, Correlation between fission tracks and fission type xenon in meteoritic whitlockite, J. Geophys. Res., 74, 4221-4232, $1969 a$.

Wasserburg, G. J., J. C. Huneke, and D. S. Burnett, Correlation between fission tracks and fission-type xenon from an extinct radioactivity, Phys. Rev. Lett., 22, 1198-1201, $1969 b$.

Wasserburg, G. J., D. N. Schramm, and J. C. Huneke, Nuclear chronologies for the galaxy, Astrophys. $J$. 157(2), L91-L96, 1969c.

Wood, J. A., Chondrites: Their metallic minerals, thermal histories, and parent planets, Icarus, 6, 1-49, 1967.

Zăhringer, J., Rare gases in stony meteorites, Geochim Cosmochim Acta, 32, 209-237, 1968.

\section{Formation Times of Meteorites and Lunar Samples}

\section{S. Burnett}

This article summarizes research since the last detailed reviews of meteorite ages by Anders [1963] and Reynolds [1967]. Only crystallization ages based on purent-daughter isotopic relationships resulting from the decay of naturally occurring radioactive nuclei will be

D. S. Burnett is with the Division of Geological Sciences, CaliCornie Institute of Technology, Pasadena 91109. discussed. The basic principles and techniques for age determinations are discussed in many of the papers cited and, along with summaries of scientific results, in several recent books [Dalrymple and Lanphere, 1969; Doe 1970; Hamilton, 1965; Schaeffer and Zähringer, 1966; Faul, 19661. However, developments in the field have made some of the material in the books obsolete.

At the end of 1966 the following results were well established:

1. An age for the earth of $4.55 \pm 0.15 \times 10^{9}$ years could be calculated by assuming that terrestrial oceanic lead evolved from the primordial lead found in troilite from some iron meteorites [Patterson, 1956],

2. Ages of about $4.6 \times 10^{9}$ years were obtained from ${ }^{87} \mathrm{Rb}-{ }^{87} \mathrm{Sr}$ analyses of chondrites by assuming an initial ${ }^{87} \mathrm{Sr} /{ }^{86} \mathrm{Sr}$ ratio inferred from $\mathrm{Ca}$-rich achondrites 
[see, e.g., Gast, 1962]. (Owing to low $\mathrm{Rb} / \mathrm{Sr}$ in Ca-rich achondrites, the ${ }^{87} \mathrm{Sr} /{ }^{86} \mathrm{Sr}$ ratio shows negligible evolution in $4-5 \times 10^{9}$ years.) Partial justification for this procedure can be obtained from the ${ }^{207} \mathrm{~Pb} /{ }^{206} \mathrm{~Pb}$ in the Nuevo Laredo achondrite, which again, under the assumption of an initial $\mathrm{Pb}$ composition from iron meteorites, corresponded to an age of $4.6 \times 10^{9}$ years [Patterson, 1956].

3. The maximum $\mathrm{K}-\mathrm{Ar}$ ages of stone meteorites (mostly chondrite analyses) were 4.5-4.6 $\times 10^{9}$ years, but there was a wide spread with some ages of less than $10^{9}$ years, presumably because of diffusive ${ }^{40} \mathrm{Ar}$ loss [see, e.g., Kirsten et al., 1963].

4. Silicate inclusions from the Weekeroo station iron meteorite yielded a $\mathrm{Rb}-\mathrm{S} r$ isochron corresponding to an age of $4.7 \pm 0.3 \times 10^{9}$ years [Wasserburg et al., 1965]; this value agreed with ages of stone meteorites and indicated that K-Ar ages of $6-10 \times 10^{9}$ years measured on the metallic phase [see, e.g., Müller and Zähringer, 1966] were not actual times.

5. The presence of radiogenic ${ }^{129} \mathrm{Xe}$ in chrondrites due to in situ decay of ${ }^{129} \mathrm{I}$ (17-m.y. half-life) [Reynolds, 1960; Jeffery and Reynolds, 1961] showed that the age of the chondrites could be equated with the age of the solar system. Excess ${ }^{131-136}$ Xe was present in Ca-rich achondrites [see, e.g., Rowe and Kuroda, 1965], presumably owing to spontaneous fission of ${ }^{244} \mathrm{Pu}$ (80-m.y. half-life).

I shall now review the meteorite age measurements of the past 4 years, summarize the state of the art through 1970 , and finally discuss age measurements on lunar samples.

The primary experimental breakthrough in the past 4 years has been for the ${ }^{87} \mathrm{Rb}^{87} \mathrm{ST}$ method. Chemical extractions of $\mathrm{Rb}$ and $\mathrm{Sr}$ with subnanogram contamination levels are now possible [see, e.g., Sanz and Wasserburg, 1969]. This ability, coupled with high sensitivity and, particularly, high precision mass spectrometry [see, e.g., Wasserburg et al., 1969a] make accurate age and initial $\left({ }^{87} \mathrm{Sr} /{ }^{86} \mathrm{Sr}\right.$ ) determinations possible on small samples with only small enrichments in ${ }^{87} \mathrm{Sr} /{ }^{86} \mathrm{Sr}$.

\section{Chondrites}

A major research problem has been obtaining $\mathrm{Rb}-\mathrm{Sr}$ ages for chondrites independent of genetic assumptions relating chondrites and achondrites. Two basic approaches have been followed.

1. Accept the petrological and chemical evidence that the various chondrite subgroups are genetically related; then try to find enough variation in $\mathrm{Rb} / \mathrm{Sr}$ among members of the subclass to construct a group isochron. As long as only chondrite falls are considered, this approach has yielded consistent ages $(T)$ and initial ${ }^{87} \mathrm{Sr} /{ }^{86} \mathrm{Sr}(I)$ for hypersthene chondrites $(T=4.48 \pm 14$ $\times 10^{9}$ years, $I=0.7008 \pm 14$ [Gopalan and Wetherill, $1968])$, bronzite chondrites $(4.69 \pm 0.14 ; 0.6983 \pm 24$ [Kaushal and Wetherill, 1969]), amphoterite chondrites (4.56 $\pm 0.15 ; 0.7005 \pm 2$ [Gopulan and Wetherill,
$1969])$, and enstatite chondrites $(4.54 \pm 0.13 ; 0.6993$ 10 (Gopalan and Wetherill, 1970]). The errors in $I$ refer to the last significant figures. These data show no signiti cant differences in evolution among the various chon. drite subclasses. In contrast to the above results, a wid scatter was obtained for whole-rock analyses of carbo ceous chondrites [Kaushal and Wetherill, 1970], a though an earlier, more limited, study by Murthy an. Compston [1965] did not show this scatter clearly. $\mathrm{K}_{2}$ ushal and Wetherill suggested, but could not prove, thit the scatter represented terrestrial contamination. This work shows that terrestrial contamination may have to be considered when 'cosmic abundances' are calculated from trace element analyses of carbonaceous chondrites.

2. Determine an 'internal isochron,' using only data from a single meteorite, by analyzing separated minerak or different physical parts (e.g., chondrules and matrix) that have differences in $\mathrm{Rb} / \mathrm{Sr}$. This approach is prefer. able, although it is more difficult than the first ap proach. Initial attempts to determine chondrite iscchrons for Peace River [Murthy and Compston, 1965]. for Bjürbole [Shields et al., 1966], and for Abee, Bruder heim, and Peace River [Shima and Honda, 1967] wers only marginally successful in that there was considerable scatter in the results for a single meteorite. The scatter does not appear to result from extraterrestrial causes [Sanz and Wasserburg, 1969]. However, in the last: years, precise internal isochrons have been obtaine from Krähenberg $\left(T=4.70 \pm 0.02 \times 10^{9}\right.$ years; $I=$ $0.6989 \mp 10$ [Kempe and Müller, 1969]), Olivenza (4.63 $\pm 0.16 ; 0.6994 \mp 17$ [Sanz and Wasserburg, 1969]), Gu areña $(4.58 \pm 0.08 ; 0.69995 \mp 15$ [Wasserburg et a. $1969 b])$, and Indarch $(4.54 \pm 0.13 ; 0.6993 \mp 10$ [Gopo lan and Wetherill, 1970]). In each case the errors represent the spread of the data $(2 \sigma)$ around a best-fit isochron. The only apparent age difference between Kra. henberg and Guareña may not be significant because of the possibility of systematic interlaboratory differences in $\mathrm{Rb}$ spike calibrations of up to $2 \%$. No signifcant $I$ differences can be resolved.

The high-temperature minerals in many chondrites appear to have retained radiogenic ${ }^{129} \mathrm{Xe}$ within $\pm 2 \mathrm{~m} . \mathrm{l}$ of each other [Hohenberg et al., 1967a; Podost $1970 a$ ]. The oldest and youngest materials (Karoond total rock and Chainpur chondrules) are separated in time by only 14 m.y.; however, this difference is signif:cant.

The presence of radiogenic ${ }^{129} \mathrm{Xe}$ in nearly ever chondrite (see, e.g., the compilation by Zahring?? [1968]) probably means that none of the low whoit rock K-Ar ages for chondrites reflects the existence of young meteorites. No new conclusions have been drawn from whole-rock K-Ar data on chondrites since the discussion by Reynolds [1967]. Additional data are com. piled by Müller and Zähringer [1969]. (See, also, Funk houser et al. [1967], Mazor et al. [1970], and Firmuti et al. [1970].) Turner [1969] has shown that the ${ }^{39} \mathrm{Ar} /{ }^{40} \mathrm{Ar}$ thermal release pattern for several hyper. sthene chondrites with whole-rock $\mathrm{K}$-Ar ages of $1 \ldots 2 \mathrm{X}$ $10^{9}$ years is consistent with their involvement in the 
500-m.y. 'collision event' for hypersthene chondrites [see, e.g., Heymann, 1967].

\section{Achondrites}

Using precise $\left(1 / 10^{4}\right){ }^{87} \mathrm{Sr} /{ }^{86} \mathrm{Sr}$ measurements, Papanastassiou and Wasserburg [1969] and Papanastassiou [1969] obtained a well-defined group isochron $(T=$ $4.47 \pm 0.24 \times 10^{9}$ years; $I=0.69898 \mp 3$ ) for nine eucrites. Because of the low $\mathrm{Rb} / \mathrm{Sr}$ ratios for these meteorites, an $I$ value could be precisely calculated for each meteorite almost independent of the age. The tight grouping of the $I$ values meant that, if the meteorites formed from a parent material having $\mathrm{Rb} / \mathrm{Sr}$ similar to type I carbonaceous chondrites, the maximum time interval over which the formation occurred was $4 \mathrm{~m} . \mathrm{y}$. This result illustrates the point that the existence of formation time differences is more readily detected by initial ${ }^{87} \mathrm{Sr} /{ }^{86} \mathrm{Sr}$ measurements than by measurements of ages (from isochron slopes). However, time intervals can be calculated only on a model basis in contrast to actual values, which are presumably obtained from ${ }^{129} \mathrm{I} /{ }^{127} \mathrm{I}$ ratios. An approximate internal isochron for Stannern $(4.1 \pm 0.7 ; 0.6991 \mp 2$ [Papanastassiou, 1969]) is consistent with the group isochron. Angra dos Reis has a distinctly more primitive $I=0.69884 \pm 4$ [Papanastassiou, 1969], which is equivalent to formation $14 \mathrm{~m} . \mathrm{y}$. before the eucrites if chondritic parent material is assumed.

Many achondrites have large excesses of ${ }^{131-136} \mathrm{Xe}$ [Rowe and Kuroda, 1965; Rowe and Bogard, 1966; Kuroda et al., 1966; Rowe, 1967; Hohenberg et al., 1967b; Munk, 1967; Hohenberg, 1970]. This excess heavy Xe has a well-defined isotopic spectrum [Eberhardt and Geiss, 1966; Hohenberg et al., 1967b; Wasserburg et al. 1969c; Hohenberg, 1970 l and is known to be due to fission, presumably ${ }^{244} \mathrm{Pu}$, by its correlation with fission tracks [Wasserburg et al., 1969c]. However, the over-all spread in the achondritic (fission ${ }^{136} \mathrm{Xe}$ )/ $/{ }^{23} \mathrm{U}$ values as summarized by Reynolds [1968] is a factor of 10 $\left(\Delta T \sim 270 \mathrm{~m} . \mathrm{y}\right.$. for $\left.{ }^{244} \mathrm{Pu}\right)$ and a factor of $5(\Delta T \sim 190$ m.y. for ${ }^{244} \mathrm{Pu}$ ) for some eucrites that should have the same age based on initial Sr measurements. The achondritic ${ }^{136} \mathrm{Xe}_{f} /{ }^{238} \mathrm{U}$ is distinctly less than that for whitlockite from the St. Severin chondrite [Wasserburg et al., $1969 \mathrm{c}$ ] but about the same as the total St. Severin [Podosek, 1970b]. The radiogenic ${ }^{129} \mathrm{Xe}$ contents of Ca-rich achondrites are small (low ${ }^{127} \mathrm{I}$ ) and uncertain, owing to the presence of comparatively large amounts of spallation ${ }^{129} \mathrm{Xe}$. However, the Ca-poor achondrites, Shallowater [Hohenberg, 1967], Pena Blanca Springs, and Bishopville [Podosek, 1970a] have large ${ }^{129} \mathrm{Xe}$ excesses. All formed within $15 \mathrm{~m} . \mathrm{y}$. of most chondrites, although the formation times of Pena Blanca Springs and Bishopville are significantly younger. The extent to which achondritic ${ }^{129} \mathrm{Xe} /{ }^{127} \mathrm{I}$ and $\left.{ }^{136} \mathrm{Xe}_{f}\right|^{238} \mathrm{U}$ values ate concordant is unclear [Reynolds, 1968].

Concordant K-Ar ages of $3.8-4.0 \times 10^{9}$ years from magnetic separates of Ca-rich achondrites [Megrue,
1966] were interpreted as showing that the low ages were not the result of Ar loss. However, Megrue did not establish that more than one K-bearing phase was being analyzed, and his conclusion must be regarded as tentative. Additional whole-rock K-Ar ages for nonchondritic stone meteorites are given by Megrue [1968], Heymann et al., [1968], and Ganapathy and Anders [1969].

The well-defined internal Rb-Sr isochron for the Norton County enstatite achondrite $(T=4.70 \pm 0.10 ; I=$ $0.700 \mp 2$ [Bogard et al., 1967]) and more recent $\mathrm{K}-\mathrm{Ar}$ age measurements [Bogard et al.. 1967; Müller and Zähringer, 1969] indicate that the $5.1 \times 10^{9}$-year K-Ar age reported by Kirsten et al. [1963] does not have time significance. A $3.7 \times 10^{9}$ year age from an internal $\mathrm{Rb}-\mathrm{Sr}$ isochron for Bishopville [Compston et al., 1965] requires confirmation because Podosek [1970a] reports an approximately chondritic ${ }^{129} \mathrm{I} / /^{127} \mathbf{I}$ and Kirsten et al. [1963] give a $4.6 \times 10^{9}$-year K-Ar age.

\section{Iron Meteorites}

The high 'ages' obtained by neutron activation K-Ar measurements on the metal phase [Müller and Zähringer, 1966; Rancitelli et al., 1967] can be explained by ${ }^{83 \mathrm{~m}} \mathrm{Kr}$ interference with the ${ }^{41}$ Ar counting [Kaiser and Zähringer, 1968] and perhaps by $\mathrm{K}$ leaching [Rancitelli and Fisher, 1968]. However, reliable ages for several iron meteorites were obtained from both of silicate inclusions by both $\mathrm{Rb}-\mathrm{Sr}$ [Burnett and Wasserburg, 1967a] and K-Ar [Bogard et al., 1968] analyses of silicate inclusions. $\mathrm{Rb}-\mathrm{Sr}$ isochrons have been determined for Weekeroo station $\left(T=4.37 \pm 0.13 \times 10^{9}\right.$ years; $I=$ $0.703 \mp 2$ [Burnett and Wasserburg, 1967a]), El Taco (4.7 $\pm 0.1 ; 0.700 \mp 1$ [ Wasserburg and Burnett, 1969 and unpublished data]), and Colomera (4.61 \pm 0.04 ; $0.69940 \mp 4$ [Sanz et al., 1970]). Weekeroo appears to be significantly more evolved than Colomera. The Colomera $I$ value is distinct from Guarena and the eucrites (equivalent to 35 and $39 \mathrm{~m} . \mathrm{y}$. of evolution, respectively, in a chondritic parent material). An isochron for Kodaikanal (3.8 $\pm 0.1 ; 0.71 \mp 2$ [Burnett and Wasserburg, $1967 \mathrm{~b}$ ]), confirmed by K-Ar measurements [Bogard et al., 1968, 1969], provides the only evidence for the formation of a meteorite at a time significantly removed from the magic number of $4.6 \times 10^{9}$ years. The ${ }^{129} \mathrm{I} /{ }^{127} \mathrm{I}$ for $\mathrm{El}$ Taco silicate indicates that El Taco cooled sufficiently to retain ${ }^{129} \mathrm{Xe}$ only $4 \mathrm{~m} . \mathrm{y}$. after most chondrites [Podosek, 1970a]. Approximately chondritic ${ }^{129} \mathrm{I} /{ }^{127} \mathrm{I}$ has been reported for Toluca silicate [Alexander et al., 1970]. The ${ }^{244} \mathrm{Pu} /{ }^{238} \mathrm{U}$ ratios estimated from excess fission tracks in diopside from $\mathrm{El}$ Taco [Schirck et al., 1969] and Toluca [Fleischter et al., 1968] are consistent with near-isochronous formation of these meteorites with chondrites.

Oversby [1970] has re-examined the problem of 'excess radiogenic' $\mathrm{Pb}$ in troilite from iron meteorites and has given arguments against possible origins for the anomalies other than contamination with terrestrial leads. Slightly revised values for 'primordial lead' were also proposed. 


\section{Summary-Meteorite Ages}

Research in the last 4 years has justified the genetic assumptions relating various meteorite classes that were previously made in calculating meteorite ages; thus, it is now known with a very high degree of certainty that almost all meteorites, the earth, and, undoubtedly, the moon formed at the time of the isolation of the solar system around $4.6 \times 10^{9}$ years ago. The more precise absolute age measurements have given times between 4.5 and $4.7 \times 10^{9}$ years; however, the relative age measurements (initial ${ }^{87} \mathrm{Sr} /{ }^{86} \mathrm{Sr},{ }^{129} \mathrm{I} /{ }^{127} \mathrm{I}$ ) have provided the most insight and indicate that objects of wildly different chemical composition all formed well within $100 \mathrm{~m} . \mathrm{y}$. of each other. Still more important, it appears possible to resolve events in this interval. Unfortunately, there is no overlap at present between meteorites with well-determined initial ${ }^{87} \mathrm{Sr} /{ }^{86} \mathrm{Sr}$ and ${ }^{129} \mathrm{I} /{ }^{127} \mathrm{I}$. Under the assumption that the attribution of achondritic fission $\mathrm{Xe}$ to ${ }^{244} \mathrm{Pu}$ can be confirmed by laboratory measurements of the fission yield spectrum, another high-resolution clock for the early solar system should be available, which has not been exploited to date. Also, new $\mathrm{Pb}$ isotopic investigations on meteorites are long overdue.

\section{Age of Lunar Samples}

Age measurements on Apollo 11 samples can be found in the Science issue (vol. 167, pp. 461-481) reporting on the First Lunar Science Conference and in papers by the same authors in volume 2 of the Geochimica Cosmochimica, Supplement 1, April 1970. The ages of Tranquillity base rocks (3.6-3.7 $\times 10^{9}$ years) appear to be best defined by high-precision $\mathrm{Rb}-\mathrm{Sr}$ internal isochrons [Albee et al., 1970; Papanastassiou et al., 1970; Compston et al., 1970] and the ${ }^{39} \mathrm{Ar} /{ }^{40} \mathrm{Ar}$ thermal release studies [Turner, 1970a]. All lower-precision $\mathrm{Rb}-\mathrm{Sr}$ studies now appear to be in essential agreement with these ages [Gopalan et al., 1970; Gast et al., 1970; Hurley and Pinson, 1970]. Only the nominally high-precision Rb-Sr study by Murthy et al. [1970] gives ages that are in serious disagreement with $3.7 \times 10^{9}$ years. Very primitive initial ${ }^{87} \mathrm{Sr} /{ }^{86} \mathrm{Sr}$ values were obtained that indicate that the moon as a whole probably did not form significantly later than $4.6 \times 10^{9}$ years [Papanastassiou et al., 1970]. Whole-rock K-Ar measurements have been of limited value for either Apollo 11 [Lunar Sample Preliminary Examination Team, 1969; Albee et al., 1970; Eberhardt et al., 1970; Marti et al., 1970; Funkhauser et al., 1970] or Apollo 12 rocks [Lunar Sample Preliminary Examination Team, 1970; Schaeffer et al., 1970], owing to loss of ${ }^{40} \mathrm{Ar}$ [Albee et al., 1970; Eberhardt et al., 1970]. The interpretation of the $\mathrm{Pb}$ isotopic data is more difficult because of the uncertainties in the initial lead compositions. The high $U$ and Th enrichments and the depletion of chalcophile elements in lunar materials imply that the initial leads may have been very radiogenic. However, Tatsumoto [1970a] and Silver [1970] show that there is no single initial lead isotopic composition that can yield concordant $\mathrm{U}-\mathrm{Pb}$ and $\mathrm{Th}-\mathrm{Pb}$ ages of $3.6-3.8 \times 10^{9}$ years for all rocks. A variety of initial leads must be assumed such that the more U-rich rocks require more radiogenic initial leads. Silver $[1970]$ argues that this assumption is unreasonable and that because approximately concordant $\mathrm{U}-\mathrm{Pb}$ ages are ob tained when either primordial or terrestrial initial lead compositions are assumed, the ${ }^{207} \mathrm{~Pb} /{ }^{206} \mathrm{~Pb}$ ages so ob tained (4.0-4.1 $\times 10^{9}$ years) may represent a primary time of crystallization, whereas the $\mathrm{Rb}-\mathrm{Sr}$ isochrons and ${ }^{39} \mathrm{Ar} /{ }^{40} \mathrm{Ar}$ ages date a secondary episode. However, as suggested by Tatsumoto [1970a], selective contamina. tion with $U$ from the country rock intruded by the Tran: quillity base lavas could produce the required correlation of $\mathrm{U}$ and initial ${ }^{207} \mathrm{~Pb}$ and ${ }^{206} \mathrm{~Pb}$ contents. In this context, it is interesting to note that the 'high-Rb rocks' [Compston et al., 1970] have distinctly higher initial ${ }^{8} \mathrm{Sr} /{ }^{36} \mathrm{Sr}$ (about 0.6994) than the low-Rb rocks (0.6991) [Albee et al., 1970; Papanastassiou et al. $1970]$.

$\mathrm{Rb}-\mathrm{Sr}$ internal isochrons for Apollo 12 basalts give ages of 3.2-3.3 $\times 10^{9}$ years [Papanastassiou and Wasserburg, 1970], which are considerably higher than were expected on the basis of relative crater densities in Oceanus Procellarum and Mare Tranquillitatis.

In an issue of Earth and Planetary Science Letters (vol. 9, pp. 93-211, 1970) devoted to rock 12013 , Turner $[1970 b]$ shows that fragments of both the light and dark portions give ${ }^{40} \mathrm{Ar} /{ }^{39} \mathrm{Ar}$ ages of $3.9 \times 10^{9}$ years. $\mathrm{Rb}-\mathrm{Sr}$ isochrons for mineral separates from two small fragments give identical ages of $4.0 \times 10^{9}$ years. however, with two distinct initial ${ }^{87} \mathrm{Sr} /{ }^{86} \mathrm{Sr}$ values $(0.7050$ and 0.7085$)$ indicating that the final local St isotopic re-equilibration occurred at that time [Lunatic Asylum, 19701. However, 'total fragment' analyses were distributed approximately along a $4.5 \times 10^{9}$-year isochron indicating that the parent material(s) of 12013 had behaved approximately as a closed system with respect to $\mathrm{Rb}$ and $\mathrm{Sr}$ in the period from 4.6 to $4.0 \times 10^{9}$ years [see, also, Schnetzler et al., 1970]. Discordant $\mathrm{U}-\mathrm{Pb}$ and $\mathrm{Th}-\mathrm{Pb}$ ages are observed for 12013 regardless of the assumed initial $\mathrm{Pb}$ compositions; however, approximately concordant $\mathrm{U}-\mathrm{Pb}$ ages of $3.7-3.9 \times 10^{9}$ years can be obtained with an appropriately chosen intial lead composition [Tatsumoto, 1970b].

The Tranquillity base soil gives a model $\mathrm{Rb}$-Sr age of $4.6 \times 10^{9}$ years [Papanastassiou et al., 1970] and concordant $\mathrm{Pb}-\mathrm{U}-\mathrm{Th}$ ages of about $4.65 \times 10^{9}$ years [Tatsimoto, 1970a; Silver, 1970; Gopalan et al., 19701. Apollo 12 soil 12070 gives a slightly lower model Rb-Sr age of $4.4 \times 10^{9}$ years [Papanastassiou and Wasserburg. 1970 ]. Because the soil is a mixture including fragments from young rocks, these values are not ages in the usuai sense; however, these striking results provide the strongest evidence that the lunar soil contains a 'magic' component or components that, either with or without significant contributions from local rocks, probably have preserved the isotopic ratios dating a major fractionation event early in the history of the moon. By volatilization and leaching experiments Silver [1970] has shown that 2 loosely bound almost $\mathrm{U}$-free $\mathrm{Pb}$ component is present in Tranquillity base soil which has a very high ${ }^{207} \mathrm{~Pb} /{ }^{206} \mathrm{~Pb}$. This component is presumably the $\mathrm{am}$ 
dent $\mathrm{Pb}$ associated with the magic component, and its presence can account for a high ${ }^{207} \mathrm{~Pb} /{ }^{206} \mathrm{~Pb}$ age. The wncordant $\mathrm{U}-\mathrm{Pb}$ and $\mathrm{Th}-\mathrm{Pb}$ ages are more difficult to understand.

In comparison, the isotopic relations in lunar samples appear to be somewhat more complex than those in meteorites. On the other hand, this complexity promises to be rich in information about the evolution of the moon. For example, it is conceivable that initial lead measurements could play the same role for lunar samples as initial $\mathrm{Sr}$ measurements have played for meteorites, only with much greater sensitivity for evolutionary differences. Moreover, the simple fact that lunar samples zame from a known solar system object of planetary size annot be overemphasized. Determination of the evolution of a small planet from isotopic studies on lunar rocks, coupled with related petrological, chemical, and geophysical studies, may be a less formidable task (given adequate sampling) than working out the evolution of the earth from measurements on terrestrial rocks. It is questionable, however, whether a sufficient sampling can be obtained in the few remaining Apollo missions to allow the proverbial 'big picture' to be assembled. An on-going program of lunar exploration is required.

\section{REFERENCES}

Athee, A. L., D. S. Burnett, A. A. Chodos, O. J. Eugster, J. C. Huneke, D. A. Papanastassiou, F. A. Podesek, G. Price Russ II, H. G. Sanz, F. Tera, and G. J. Wasserburg, Ages, irradiation history, and chemical composition of lunar rocks from the Sea of Tranquillity, Science, 167, 463-465, 1970.

Alexander, E. C., Jr., B. Srinivasan, and O. K. Manuel, I-Xe dating of silicates from Toluca iron, Earth Planet. Sci. Lett., 8, $188,1970$.

Anders, E., Meteorite ages, in The Solar System, vol. 4, The Woon, Meteorites, and Comets, edited by B. M. Middlehurst and G. P. Kuiper, University of Chicago Press, Chicago, Ill., 1963. Bogard, D. D., D. S. Burnett, P. Eberhardt, and G. J. Wasserburg, $\mathrm{Rb}^{87}-\mathrm{Sr}^{87}$ isochron and $\mathrm{K}^{40}-\mathrm{Ar}^{40}$ ages of the Norton County achondrite, Earth Planet. Sci. Lett., 3, 179-189, 1967.

Bogard, D. D., D. S. Burnett, P. Eberhardt, and G. J. Wasserburg, $\mathrm{Ar}^{40}-\mathrm{K}^{40}$ ages of silicate inclusions in iron meteorites, Earth Planet. Sci. Lett., 3, 275-283, 1968.

Bogard, D. D., D. S. Burnett, and G. J. Wasserburg, Cosmogenic rare gases and the $\mathrm{K}^{40}-\mathrm{Ar}^{40}$ age of the Kodaikanal iron meteorite, Earth Planet. Sci. Lett., 5, 273-281, 1969.

Burnett, D. S., and G. J. Wasserburg, $\mathrm{Rb}^{87}-\mathrm{Sr}^{87}$ ages of silicate inclusions in iron meteorites, Earth Planet. Sci. Lett., 2, $397-408,1967 a$.

Burnett, D. S., and G. J. Wasserburg, Evidence for the formation of an iron meteorite at $3.8 \times 10^{9}$ years, Earth Planet. Sci. Lett., 2, 137-147, $1967 \mathrm{~b}$.

Compston, W., J. F. Lovering, and M. J. Vernon, The rubidiumstrontium age of the Bishopville aubrite and its component enstatite and feldspar, Geochim. Cosmochim. Acta, 29, $1085-1099,1965$.

Compston, W., B. W. Chappell, P. A. Arriens, and M. J. Vernon, The chemistry and age of Apollo 11 lunar material, Geochim. Cosmochim. Acto, Suppl. 1, 1007-1028, 1970.

Dalrymple, G. B., and M. A. Lanphere, Potassium-Argon Dating; Principles, Techniques and Applications to Geochemistry, W. H. Freeman, San Francisco, Calif., 1969.

Ihe, B., Lead Isotopes, Springer-Verlag, New York, 1970.

Fberhardt, P., and J. Geiss, On the mass spectrum of fission xenon in the Pasamonte meteorite, Earth Planet. Sci. Lett., l, $99-102,1966$.

Eberhardt, P., O. Eugster, J. Geiss, and K. Marti, Rare gas measurements in 30 stone meteorites, Z. Naturforsch., 21a, $414-426,1966$.
Eberhardt, P., J. Geiss, H. Graf, N. Grogler, U. Krähenbuhl, H. Schwaller, J. Schwarzmuller, and A. Stettler, Trapped solar wind noble gases, $\mathrm{Kr}^{81} / \mathrm{Kr}$ exposure ages and $\mathrm{K} / \mathrm{Ar}$ ages in Apollo 11 lunar material, Science, 167, 558-560, 1970.

Faul, H., Ages of Rocks, Planets, and Stars, McGraw-Hill, New York, 1966.

Fireman, E., J. DeFelice, and E. Norton, Ages of the Allende meteorite, Geochim. Cosmochim. Acta, 34, 873-881, 1970.

Fleischer, R. L., P. B. Price, and R. M. Walker, Identification of $\mathrm{Pu}^{244}$ fission tracks and the cooling of the parent body of the Toluca meteorite, Geochim. Cosmochim. Acta, 32, 21-31, 1968.

Funkhouser, J., T. Kirsten, and O. A. Schaeffer, Light and heavy rare gases in four fragments of the St. Severin meteorite, Earth Planet. Sci. Lett., 2, 185-190, 1967.

Funkhouser, J. G., O. A. Schaeffer, D. D. Bogard, and $J$ Zähringer, Gas analysis of the lunar surface, Science, 167, $561-562,1970$.

Ganapathy, R., and E. Anders, Ages of calcium-rich achondrites, 2, Howardites, nakhlites, and the Angra dos Reis angrite, Geochim. Cosmochim. Acta, 33, 775-787, 1969.

Gast, P. W., The isotopic composition of strontium and the age of stone meteorites, 1, Geochim. Cosmochim. Acta, 26, $927-943,1962$.

Gast, P. W., N. J. Hubbard, and H. Wiesmann, Chemical composition and petrogenesis of basalts from Tranquillity base, Geo chim. Cosmochim. Acta, Suppl. 1, 1143-1164, 1970.

Gopalan, K., and G. W. Wetherill, Rubidium-strontium age of hypersthene (L) chondrites, J. Geophys. Res., 73, 7133-7136, 1968.

Gopalan, K., and G. W. Wetherill, Rubidium-strontium age of amphoterite (LL) chondrites, J. Geophys. Res., 74. $4349-4358,1969$

Gopalan, K., and G. W. Wetherill, Rb-Sr studies on enstatite chondrites: whole meteorite and mineral isachrons, $J$. Geo phys, Res., 75, 3457-3467, 1970.

Gopalan, K., S. Kaushal, C. Lee-Hu, and G. W. Wetherill, Rb/Sr and $\mathrm{U}, \mathrm{Th}-\mathrm{Pb}$ ages of lunar materials, Geochim. Cosmochim. A cta, Suppl. 1, 1195-1206, 1970.

Hamilton, E. I., Applied Geochronology, Academic, New York, 1965.

Heymann, D., On the origin of hypersthene chondrites: Ages and shock effects of black chondrites, Icarus, 6, 189-221, 1967.

Heymann, D., E. Mazor, and E. Anders, Ages of calcium-rich achondrites, 1, Eucrites, Geochim. Cosmochim. Acto, 32 , $1241-1268,1968$.

Hohenberg, C. M., I-Xe dating of the Shallowater achondrite, Earth Planet. Sci. Lett., 3, 357-362, 1967.

Hohenberg, C. M., Xenon from the Angra dos Reis meteorite, Geochim. Cosmochim. Acta, 34, 185-191, 1970.

Hohenberg, C. M., F. A. Podosek, and J. H. Reynolds, Xenoniodine dating: Sharp isochronism in chondrites, Science, 156, 233-236, 1967a.

Hohenberg, C. M., M. N. Munk, and J. H. Reynoids, Spallation and fissiogenic xenon and krypton from stepwise heating of the Pasamonte achondrite; the case for extinct plutonium 244 in meteorites; relative ages of chondrites and achondrites, $J$. Geophys. Res., 72, 3139-3177, 1967b.

Hurley, P. M., and W. H. Pinson, Jr., Whole-rock Rb-Sr isotopic age relationships in Apollo 11 lunar samples, Geochim. Cosmochim. Acta, Suppl. 1, 2,1311-1316, 1970.

Jeffery, P. M., and J. H. Reynolds, Origin of excess $\mathrm{Xe}^{129}$ in stone meteorites, J. Geophys. Res., 66, 3582-3583, 1961.

Kaiser, W., and J. Zahringer, K.Ar age determinations of iron meteorites, 4, New results with refined experimental procedures, Earth Planet. Sci. Lett., 4, 84-88, 1968.

Kaushal, S. K., and G. W. Wetherill, $\mathrm{Rb}^{87}-\mathrm{Sr}^{87}$ age of bronzite (H group) chondrites, J. Geophys. Res., 74. 2717-2726, 1969.

Kaushal, S. K., and G. W. Wetherill, $\mathrm{Rb}^{87}-\mathrm{Sr}^{87}$ age of carbonaceous chondrites, J. Geophys. Res., 75, 463-469, 1970.

Kempe, W., and $O$. Müller, The stony meteorite Krähenberg: Its chemical composition and the $\mathrm{Rb}-\mathrm{Sr}$ age of the light and dark portions, (International Symposium on Meteorite Research, Vienna, August 7-13,1968), in Meteorite Research, edited by 
P. M. Millman, pp. 418-428, D. Reidel, Dordrecht, Holland, 1969.

Kirsten, T., D. Kranknowsky, and J. Zähringer, Edelgas und kalium Bestimmungen an einer grösseren Zahl von Steinmeteoriten, Geochim. Cosmochim. Acta, 27, 13-42, 1963.

Kuroda, P. K., M. W. Rowe, R. S. Clark, and R. Ganapathy, Galactic and solar nucleosynthesis, Nature, 212, 241-243, 1966.

Lunar Sample Preliminary Examination Team, Preliminary examination of lunar samples from Apollo 11, Science, 165, $1211-1127,1969$.

Lunar Sample Preliminary Examination Team, Preliminary examination of lunar samples from Apollo 12, Science, 167, $1325-1339,1970$.

Lunatic Asylum, Mineralogic and isotopic investigations on lunar rock 12013, Earth Planet. Sci. Lett., 9, 137-168, 1970.

Marti, K., G. W. Lugmuir, and H. C. Urey, Solar wind gases, cosmic ray spallation products and the irradiation history of Apollo 11 samples, Geochim. Cosmochim. Acta, Suppl. I, $1357-1368,1970$.

Mazor, E., D. Heymann, and E. Anders, Noble gases in carbonaceous chondrites, Geochim. Cosmochim. Acta, 34, $781-824,1970$.

Megrue, G. H., Rare gas chronology of calcium-tich achondrites, J. Geophys. Res., 71, 4021-4027, 1966.

Megrue, G. H., Rare gas chronology of hypersthene achondrites and pallasites, J. Geophys. Res., 73, 2027-2033, 1968.

Müller, O., and J. Załhringer, K-Ar Altersbestimmungen an Eisenmeteoriten, 3, Kalium- und Argon-Bestimmungen, Geochim. Cosmochim. Acta, 30, 1075-1092, 1966.

Müller, O., and J. Zähringer, Rare gases in stony meteorites (International Symposium on Meteorite Research), in Meteorite Research, edited by P. M. Millman, pp. 845-856, D. Reidel, Dordrecht, Holland, 1969.

Munk, M. N., Argon, krypton, and xenon in Angra dos Reis, Nuevo Laredo, and Norton County achondrites: The case for two types of fission xenon in achondrites, Earth Planet. Sci. Lett., 3, 457-465, 1967.

Murthy, V. R., and W. Compston, Rb-Sr ages of chondrites and carbonaceous chondrites, J. Geophys. Res., 70, 5297-5307, 1965.

Murthy, V. R., N. M. Evenson, and M. R. Coscio, JI., Distribution of $\mathrm{K}, \mathrm{Rb}, \mathrm{Sr}$ and $\mathrm{Be}$ and $\mathrm{Rb}-\mathrm{Sr}$ isotopic relations in Apollo 11 lunar samples, Geochim. Cosmochim. Acta, Suppl. 1, $1393-1403,1970$

Oversby, V. M., The isotopic composition of lead in iron meteorites, Geochim. Cosmochim. Acta, 34, 65-76, 1970.

Papanastassiou, D. A., The determination of small time differences in the formation of planetary objects, Ph.D. thesis, California Institute of Technology, Pasadena, 1969.

Papanastassiou, D. A., and G. J. Wasserburg, Initial strontium isotopic abundances and the resolution of small time differences in the formation of planetary objects, Earth Planet. Sci. Lett., 5, 361-376, 1969.

Papanastassiiou, D. A., and G. J. Wasserburg, Rb-Sr ages from the ocean of storms, Earth Planet. Sci. Lett., 8, 269-278, 1970.

Papanastassiou, D. A., G. J. Wasserburg, and D. S. Burnett, Rb-Sr ages of lunar rocks from the Sea of Tranquillity, Earth Planet. Sci. Lett., 8, 1-19, 1970.

Patterson, C. C., Age of meteorites and the earth, Geochim. Cosmochim. Acta, 10, 230-237, 1956.

Podosek, F. A., Dating of meteorites by the high-temperature release of iodine-correlated $\mathrm{Xe}^{129}$, Geochim. Cosmochim. Acta, 34, 341-365, 1970a.

Podosek, F. A., The abundance of $\mathrm{Pu}^{244}$ in the early solar system, Earth Planet. Sci. Lett., 8, 183-187, 1970 b.

Pinson, W. H., Jr., C. C. Schnetzler, E. Beiser, H. W. Fairbarin, and P. M. Hurley, $\mathrm{Rb}-\mathrm{Sr}$ age of stony meteorites, Geochim. Cosmochim. Acta, 29, 455-466, 1965.

Rancitelli, L. A., and D. E. Fisher, Potassium:argon problem in iron meteorites, J. Geophys. Res., 73, 5429-5438, 1968.

Rancitelli, L., D. E. Fisher, J. Funkhouser, and O. A. Schaeffer, Potassium:argon dating of iron meteorites, Science, 155, $999-1000,1967$.
Reynolds, J. H., Isotopic composition of primordial xenon Phys. Rev. Lett., 4, 351-352, 1960.

Reynolds, J. H., Isotopic abundance anomalies in the solar sys. tem, Ann. Rev. Nucl. Sci., 17, 253-316, 1967. Reynolds, J. H., Plutonium-244 in the early solar system, $N_{*}$
ture, $218,1024-1028,1968$.

Rowe, M. W., Cosmic ray produced Xe and the special anomat in achondrites, Earth Planet. Sci. Lett., 2, 92-97, 1967.

Rowe, M. W., and P. K. Kuroda, Fissiogenic xenon from the Pasamonte meteorite, J. Geophys. Res., 70, 709-714, 1965

Rowe, M. W., and D. D. Bogard, Xenon anomalies in the monte meteorite, J. Geophys. Res., 71, 686-687, 1966.

Sanz, H. G., and G. J. Wasserburg, Determination of an internal $\mathrm{Rb}^{\mathbf{3} 7}-\mathrm{Sr}^{\mathbf{3}} \mathbf{7}$ isochron for the Olivenza chondrite, Earth Plenet Sci. Lett., 6, 335-345, 1969.

Sanz, H. G., D. S. Burnett, and G. J. Wasserburg, A precise $\mathrm{Rb}^{87} / \mathrm{Sr}^{87}$ age and initial $\mathrm{Sr}^{87} / \mathrm{Sr}^{86}$ for the Colomera ires meteorite, Geochim. Cosmochim. Acta, 34, 1227-1240, 1970

Schaeffer, O., and J. Zahringer (Ed.), Potassium-Argon Dating. Springer-Verlag, New York, 1966.

Schaeffer, O. A., J. G. Funkhouser, D. D. Bogard, and J. Zat. ringer, Potassium-argon age of lunar rocks from Mare Tranquir litatis and Oceanus Procellarum, Science, 170, 161-162, 1970 .

Schirck, J. M. Hoppe, M. Maurette, R. Walker, R. L. Fleischer, and P. B. Price, Recent fossil track studies bearing on extinct $\mathrm{Pu}^{24} 4$ in meteorites (International Symposium on Meteorite Re. scarch, Vienna, August 7-13, 1968), in Meteorite Research, edited by P. M. Millman, pp. 41-51, D. Reidel, Dordrecht. Holland, 1969.

Schnetzler, C. C., J. A. Philpotts, and M. L. Bottino, Li, K, Rb, $\mathrm{Sr}, \mathrm{Ba}$ and rare earth concentrations, and $\mathrm{Rb}-\mathrm{Sr}$ age of lunar rock 12013, Earth Planet. Sci. Lett., 9, 185-192, 1970.

Shields, R. M., W. H. Pinson, Jr., and P. M. Hurley, Rb-Sr anat yses of the Bjurböle chondrite, J. Geophys. Res., 71. 2163-2168, 1966.

Shima, M., and M. Honda, Determination of rubidium-strontium age of chondrites using their separated components, Earth Planet. Sci. Lett., 2, 337-343, 1967.

Silver, L. T., U-Th-Pb isotopes in some Tranquillity base samples and their implications for lunar history, Geochim. Cosmochim Acta, Suppl. 1, 1533-1574, 1970.

Tatsumoto, M., Age of the moon-an isotopic study of U-Th-Pt systematics of Apollo 11 lunar samples, 2, Geochim. Cosmochim. Acta, Suppl. 1, 1595-1612, 1970a.

Tatsumoto, M., U-Th-Pb age of Apollo 12 rock 12013, Etrh Planet. Sci. Lett., 9, 193-200, 1970 b.

Turner, G., Thermal histories of meteorites by the $\mathrm{Ar}^{39}{ }^{4} \mathrm{Ar}^{40}$ method, (International Symposium on Meteorite Research, V. enna, August $7-13,1968$ ), in Meteorite Research, edited by P. M. Millman, pp. 407-417, D. Reidel, Dordrecht, Holland, 1969

Turner, G., $\mathrm{Ar}^{39} / \mathrm{Ar}^{40}$ dating of lunar rocks, Geochim. Cosmo chim. Acta, Suppl. 1, 1665-1684, 1970a.

Turner, G., $\mathrm{Ar}^{40} / \mathrm{Ar}^{39}$ age determination of lunar rock 12013 Earth Planet. Sci. Lett., 9, 177-180, 1970 b.

Wasserburg, G. J., and D. S. Burnett, The status of isotopic age determinations on iron and stone meteorites (Internationai Symposium on Meteorite Research, Vienna, August 7-13. 1968), in Meteorite Research, edited by P. M. Millman, p. 467-479, D. Reidel, Dordrecht, Holland, 1969.

Wasserburg, G. J., D. S. Burnett, and C. Frondel, Strontium rubidium age of iron meteorite, Science, 150, 1814-1818. 1965.

Wasserburg, G. J., D. A. Papanastassiou, E. V. Nenow, and C. A Bauman, A programmable magnetic field mass spectrometer with on-line data processing, Rev. Sci. Instrum., 40, 288-295 $1969 a$.

Wasserburg, G. J., D. A. Papanastassiou, and H. G. Sanz, Initz] strontium for a chondrite and the determination of a metamorphism or formation interval, Earth Planet. Sci. Lett., 7, 33-43, $1969 b$.

Wasserburg, G. J., J. C. Huneke, and D. S. Burnett, Correlation between fission tracks and fission type xenon in meteoriti whitlockite, J. Geophys. Res., 74, 4221-4232, 1969c.

Zähringer, J., Rare gases in stony meteorites, Geochim. Cosmo chim. Acta, 32, 209-238, 1968. 